\title{
Unusual chemical composition of a Mexican propolis collected in
}

\section{Quintana Roo, Mexico}

Séverine Boisard, ${ }^{\mathrm{a}}$ Thi Huong Tho Huynh, ${ }^{\mathrm{a}}$ Fabiola Escalante-Erosa, ${ }^{\mathrm{b}}$ Luis

Ignacio Hernández-Chavez, ${ }^{\mathrm{c}}$ Luis Manuel Peña-Rodríguez, ${ }^{\mathrm{b}}$ and Pascal

Richomme $^{\mathrm{a}, *}$

${ }^{a}$ EA 921 SONAS/SFR 4207 QUASAV, Université d'Angers, 16 Bd Daviers ,49045 Angers Cedex 01, France

${ }^{b}$ Unidad de Biotecnologia, Centro de Investigación Cientifica de Yucatán, Mérida, Yucatán, México

${ }^{c}$ Instituto Superior de Felipe Carrillo Puerto, Carrillo Puerto Quintana Roo, México

*Corresponding author : pascal.richomme@univ-angers.fr 


\section{SUMMARY}

Propolis is a resinous natural substance collected by honeybees from buds and exudates of various trees and plants; it is widely accepted that the composition of propolis depends on the phytogeographic characteristics of the site of collection. In this study we have analyzed the chemical composition of a propolis collected in Quintana Roo, Mexico, and evaluated its antioxidant, antifungal and antibacterial activities. Unexpectedly, the chemical analysis showed that the main components of the ethanolic extract of a Mexican propolis appeared to be pentacyclic triterpenoids, such as $\alpha$ and $\beta$-amyrin derivatives, and sterols. The crude extract did not show antioxidant activity when tested using the DPPH-reduction assay, and it also proved inactive when tested for antifungal and antibacterial activities using microdilution and agar diffusion assays, respectively. The fact that the presence of both $\alpha$ and $\beta$-amyrins and their derivatives have been reported from the resin of Bursera simaruba, one of the plants used by the bees for propolis production in Quintana Roo, Mexico, confirms the relationship that exists between the flora available to bees in a given region and the chemical composition of the propolis that they produce. 


\section{RESUMEN}

El propóleo es un producto natural resinoso colectado por abejas a partir de brotes y exudados de diferentes plantas y árboles; es ampliamente aceptado que la composición del propóleo depende de las características fitogeográficas del sitio de colecta. En este estudio analizamos la composición química de un propóleo colectado en Quintana Roo, México, y evaluamos sus actividades antioxidante, antifúngica y antibacteriana. Inesperadamente, el análisis químico mostró que los principales componentes del extracto etanólico del propóleo mexicano parecían ser triterpenoides pentacíclicos, tales como derivados de $\alpha$ y $\beta$-amyrina y esteroles. El extracto crudo no mostró actividad antioxidante al ser evaluado en el ensayo de reducción de DPPH, y también se mostró inactivo al ser evaluado en cuanto a su actividad antifúngica y antibacteriana utilizando los ensayos de microdilución y de difusión en agar, respectivamente. El hecho de que la presencia de $\alpha$ y $\beta$-amyrina y sus derivados ya se ha reportado en la resina de Bursera simaruba, una de las plantas utilizadas por las abejas para su producción de propóleo en Quintana Roo, México, confirma la relación que existe entre la flora disponible para las abejas en una región en particular y la composición química del propóleo que producen.

Keywords: Mexican propolis, pentacyclic triterpenes, amyrins, sterols, Bursera simaruba

Short title: Chemical composition of a Mexican propolis 


\section{INTRODUCTION}

Propolis is a resinous natural substance collected by honeybees from buds and exudates of various trees and plants, mixed with beeswax and salivary enzymes. Bees generally use propolis to seal and smooth out the internal walls of the hive, as well as a protective barrier against fungal and bacterial infections. Propolis has been used in folk medicine since ancient times due to its pharmacological potential associated with antioxidant (Cottica et al. 2011; Gülçin et al. 2010; Miguel et al. 2010), antifungal (Ota et al. 2001; Sawaya et al. 2002), antibacterial (Kujumgiev et al. 1999; Popova et al. 2005; Raghukumar et al. 2010) and antiinflammatory (Castaldo and Capasso, 2002) properties.

Propolis is generally composed of 50\% resin and balm (including polyphenolic compounds), $30 \%$ wax and fatty acids, $10 \%$ essential oils, $5 \%$ pollen and $5 \%$ various organic and inorganic compounds. Presently it is widely accepted that the composition of propolis depends on the phytogeographic characteristics of the site of collection (Marcucci, 1995; Sforcin and Bankova, 2011) and a number of attempts have been made to define propolis types taking into account geographic origin, chemical composition, and plant source (Park et al. 2002; Salatino et al. 2005; Sforcin and Bankova, 2011; Trusheva et al. 2006); recently, five propolis types have been defined according to their chemogeographic patterns (Salatino et al. 2011). It is also generally accepted that propolis from temperate climatic zones, like Europe, North America and non-tropical regions of Asia, originate mainly from the bud exudates of Populus species and are rich in flavonoids, phenolic acids and their esters (Bankova et al. 2000), while propolis from tropical regions, where no poplars and birches exist, are rich in prenylated derivatives of $p$-coumaric acid and benzophenons (Bankova, 2005a; Kumazawa et al. 2004; Sforcin and Bankova, 2011); other examples include lignan-containing propolis from Chile, Spain and Kenya, and a propolis from Myanmar containing cycloartanes and prenylated flavanones (Salatino et al. 2011). 
Mexico is considered as one of the three most important honey exporters in the world, with around $40 \%$ of its production located in and around the Yucatan peninsula (Pino et al. 2006). However, in spite of its potential importance, studies on the chemical composition and biological activity of Mexican propolis are limited. A chemical investigation of a red propolis sample collected in Campeche, in the southeast region of Mexico, reported the presence of flavanones, isoflavans and pterocarpans, suggesting a possible relationship between the chemical composition of the Mexican red propolis and plants of the Dalbergia genus (Lotti et al. 2010). Other investigations report the antimicrobial activity against gram negative bacteria of several propolis samples collected in Campeche, Mexico (Tolosa and Canizares, 2002), the correlation between antimicrobial activity and composition of propolis and plants collected in central Mexico (Londono Orozco et al. 2010), and the identification by GC-MS of over 100 volatile constituents from two propolis samples collected in Yucatan, Mexico (Pino et al. 2006). Finally, a study on the chemical composition and biological activity of three propolis samples collected in different arid and semiarid regions of Sonora, Mexico showed cinnamic and phenylpropanoic acid derivatives and flavonoids as the main components, and antibacterial, free-radical scavenging, and cytotoxic activities (Li et al. 2010; Velazquez et al. 2007). We wish to report herein on the evaluation of the antioxidant, antifungal and antibacterial activities of a tropical propolis sample from Quintana Roo, a state in the Yucatan peninsula of Mexico, and the unexpected identification of pentacyclic triterpenoids and sterols as the only components present in its ethanolic extract.

\section{MATERIALS AND METHODS}

Chemicals. 1,1-Diphenyl-2-picrylhydrazyl (DPPH), Folin-Ciocalteu reagent, formic acid, and gallic acid, all analytical grade, were purchased from Sigma-Aldrich (St Quentin Fallavier, 
France). 6-Hydroxy-2,5,7,8-tetramethylchroman-2-carboxylic acid (Trolox ${ }^{\circledR}$ ) and 5'caffeoylquinic acid (chlorogenic acid) were obtained from Acros Organics (Geel, Belgium).

Propolis sample. The propolis sample (224 g), collected from apiaries located in the area of Macario Gómez in Solidaridad, Quintana Roo, Mexico, was obtained from the Dzidzilche honey-distributing store of the "Productores y Realizadores de Miel Maya" cooperative.

Extractions. Propolis was first pulverized in the presence of liquid nitrogen into a homogenous powder. A $1 \mathrm{~g}$ portion of propolis powder was extracted three times with ethanol $(20 \mathrm{~mL})$ at room temperature for $2 \mathrm{~h}$; the combined filtrates were maintained at $-18^{\circ} \mathrm{C}$ overnight, filtered to remove waxes, and evaporated under reduced pressure to dryness to give the ethanolic extract (E1a). A second $1 \mathrm{~g}$ portion of propolis was successively extracted with cyclohexane (E2, 3x20 mL, 2h), DCM (E3, 3x10 mL, 2h), EtOAc (E4, 3x10 mL, 2h), and $\mathrm{MeOH}(\mathbf{E 5}, 3 \times 10 \mathrm{~mL}, 2 \mathrm{~h})$ to produce the corresponding low, medium low, medium high, and high polarity extracts.

Determination of total polyphenol content. Total polyphenol content was determined according to the Folin-Ciocalteu colorimetric method (Rebiai et al. 2011); $20 \mu \mathrm{L}$ of extract solution $(2.5 \mathrm{mg} / \mathrm{mL})$ in $\mathrm{MeOH}$ were mixed with $280 \mu \mathrm{L}$ of distilled water and $100 \mu \mathrm{L}$ of Folin-Ciocalteu's phenol reagent. After $3 \mathrm{~min}, 1200 \mu \mathrm{L}$ of distilled water and $400 \mu \mathrm{L}$ of $20 \%$ aqueous sodium carbonate solution were added and $200 \mu \mathrm{L}$ of each solution were put into a 96-well microtiter plate. A blank was prepared in the same way by using $\mathrm{MeOH}$ instead of the extract solution. The absorbance was measured on a Tecan Infinite M200 microplate spectrophotometer, at $760 \mathrm{~nm}$ after $30 \mathrm{~min}$ in the dark, at room temperature. Gallic acid was used to calculate the calibration curve $\left(0.4-1.2 \mathrm{mg} / \mathrm{mL} ; \mathrm{y}=0.5800 \mathrm{x} ; \mathrm{r}^{2}=0.9941\right)$ and the total 
polyphenol content was expressed as milligram of Gallic Acid Equivalent per gram of extract (mg GAE/g). The determination was performed in triplicate.

HPLC-DAD procedure. $10 \mathrm{mg}$ of extracts were dissolved in $1 \mathrm{~mL}$ of $\mathrm{MeOH}$ and centrifuged at $13000 \mathrm{rpm}$ for $10 \mathrm{~min}$ prior to injection $(10 \mu \mathrm{L})$. HPLC analyses were run on a 2695 Waters ${ }^{\circledR}$ separation module equipped with a diode array detector 2996 Waters ${ }^{\circledR}$. Separations were carried out on a Lichrospher ${ }^{\circledR}$ column $100 \mathrm{RP}-18(125 \mathrm{x} 4 \mathrm{~mm}$ i.d., $5 \mu \mathrm{m})$ protected with a Lichrocart $\left.{ }^{(}\right)$-4 guard cartridge $(4 \times 4 \mathrm{~mm}$ i.d.), using a flow rate of $1 \mathrm{~mL} / \mathrm{min}$. The mobile phase consisted of $0.1 \%$ formic acid in water (solvent A) and methanol (solvent B) and the separation was performed by the following linear gradient: $25-100 \% \mathrm{~B}(0-40 \mathrm{~min}), 100 \% \mathrm{~B}$ (40-45 min). UV detection was achieved at three wavelengths: 254, 280 and $350 \mathrm{~nm}$.

Analytical TLC. Analytical TLC was performed on TLC Alugram Xtra SIL G/UV 254 , using a mixture of cyclohexane:AcOEt 85:15 as eluant. Spots in the chromatogram were visualized by spraying with vanillin-sulfuric acid reagent $(2 \mathrm{~mL}$ of concentrated sulfuric acid in $98 \mathrm{~mL}$ of a 1:99 w/v vanillin: $95 \%$ ethanol solution) and heating the chromatograms at $110^{\circ} \mathrm{C}$ for five minutes.

Fractionation by Flash Chromatography. $18 \mathrm{~g}$ of propolis powder were macerated in ethanol (6 x $200 \mathrm{~mL}, 2$ h) to give, after solvent evaporation, $4.2 \mathrm{~g}$ of crude extract E1b. E1b was totally dissolved in the minimum volume of DCM and the solution was mixed with $8.4 \mathrm{~g}$ of silica gel. The solvent was allowed to evaporate until a fine dry powder was obtained. The fractionation was performed by using a CombiFlash Teledyne ISCO apparatus with a silica gel column (Redisep silica $80 \mathrm{~g}$ ), with a gradient elution of $100 \%$ cyclohexane to $100 \%$ 
EtOAc, and a flow rate of $35 \mathrm{~mL} / \mathrm{min} .200$ tubes of $20 \mathrm{~mL}$ were collected and combined into 10 fractions on the basis of their TLC chromatographic profiles (cyclohexane: EtOAc 85:15).

${ }^{1} \mathbf{H}$ and ${ }^{13} \mathbf{C}$ NMR analyses. NMR spectra were recorded in $\mathrm{CDCl}_{3}$ using a Bruker Avance spectrometer at $500 \mathrm{MHz}$ for ${ }^{1} \mathrm{H}$ and $125 \mathrm{MHz}$ for ${ }^{13} \mathrm{C}$.

GC-MS procedure. The GC-MS analysis was performed on non-derivatized samples using an Agilent Technologies Gas Chromatograph 6890N connected to an Agilent Technologies 5975B mass detector system with an ionization voltage of $70 \mathrm{eV}$. Separations were carried out using a $30 \mathrm{~m}$ long, $0.32 \mathrm{~mm}$ id, $0.5 \mathrm{~mm}$ film ultra $1100 \%$ dimethylpolyxiloxane column. The temperature was programmed as follows: $180^{\circ} \mathrm{C}(3 \mathrm{~min}), 180-280^{\circ} \mathrm{C}$ at the rate of $10^{\circ} \mathrm{C} / \mathrm{min}$ and $280^{\circ} \mathrm{C}(30 \mathrm{~min})$. Helium was used as a carrier gas at a flow rate $1.5 \mathrm{~mL} / \mathrm{min}$. Injector and detector temperatures were set at 250 and $280^{\circ} \mathrm{C}$, respectively. Metabolites were identified by comparing their retention times and/or their fragmentation patterns with those of authentic samples and/or those contained in the fragmentation pattern library of the equipment (NIST Library in Chem Station G1701DA).

Evaluation of antioxidant activity using the DPPH assay. The assay was carried following a modified procedure on a reported methodology (Abdel-Lateff et al. 2002). Sample and standards were diluted in absolute ethanol at $0.02 \mathrm{mg} / \mathrm{mL}$ from stock solutions prepared at 1 $\mathrm{mg} / \mathrm{mL}$ in DMSO; $100 \mu \mathrm{L}$ aliquots of these solutions were placed in 96-well plates and the reaction was initiated by adding $25 \mu \mathrm{L}$ of freshly prepared DPPH solution (1mM) and $75 \mu \mathrm{L}$ of absolute ethanol using the microplate reader's injector (Infinite ${ }^{\circledR} 200$, Tecan, France) to obtain a final volume of $200 \mu \mathrm{L}$ per well. After 30 minutes in the dark and at room temperature, the absorbance was determined at $517 \mathrm{~nm}$. Ethanol was used as a blank, whereas 
$10,25,50$, and $75 \mu \mathrm{M}$ solutions of Trolox (hydrophilic $\alpha$-tocopherol analog) were used as calibration solutions. A sample of $0.02 \mathrm{mg} / \mathrm{mL}$ chlorogenic acid was used as a quality control. The evaluation was carried out in triplicate. The DPPH-scavenging activity was compared with that of Trolox using the calibration curve. Result was expressed in terms of Trolox equivalents (micromoles of Trolox equivalents per gram of extract).

Evaluation of the antifungal activity. Antifungal activity was assayed on human pathogenic fungi, including a yeast (Candida albicans ATCC 66396) and an opportunistic mould (Aspergillus fumigatus CBS 11326). The strains were obtained from the parasitology and mycology laboratory, University Hospital Center, Angers, France. Both microorganisms were cultivated at $37{ }^{\circ} \mathrm{C}$ on yeast extract-peptone-dextrose agar (YPDA) containing $0.5 \mathrm{~g} / \mathrm{L}$ chloramphenicol for two (C. albicans) or three (A. fumigatus) days. Tests were performed according to a procedure described by Alomar et al. (Alomar et al. 2012) following the guidelines of the approved reference method of the National Committee for Clinical Laboratory Standards (NCCLS) for yeasts (NCCLS, 1997) and filamentous fungi (NCCLS, 2002). Briefly, the yeast suspensions were prepared in RPMI-1640 culture medium and adjusted spectrophotometrically at $630 \mathrm{~nm}$ to reach a final concentration of $c a .0 .5 \times 10^{3}$ to $2.5 \times 10^{3}$ cells $/ \mathrm{mL}$. The tests were performed using sterile 96 flat shaped well microtiter plates. Serial two-fold sample dilutions were made in DMSO. Sample solutions (E1a and fractions A, $\mathrm{B}$ and $\mathrm{C}$ ) were dispensed at a volume of $5 \mu \mathrm{L}$ in triplicate into the wells to obtain final concentrations from 250 to $1.95 \mu \mathrm{g} / \mathrm{mL}$. After $48 \mathrm{~h}$ at $37^{\circ} \mathrm{C}$ for C. albicans, and $72 \mathrm{~h}$ for $A$. fumigatus, the spectrophotometric MIC endpoint was calculated from the turbidimetric data as the lowest sample concentration causing a growth inhibition equal to or greater than $80 \%$ of the control $\left(\mathrm{MIC}_{80}\right)$. Amphotericin B was used as a positive control. 
Evaluation of antibacterial activity. Antibacterial activity was evaluated on 21 bacterial strains obtained from the laboratory of bacteriology, University Hospital Center, Angers, France: seven strains of Acinetobacter baumannii (RCH, SAN008, 12, AYE, CIP7034, CIP107292, CIP5377), five of Staphylococcus aureus (ATCC25923, two methicillin-sensitive clinical isolates, two methicillin-resistant clinical isolates), two of Escherichia coli (ATCC25922 and a clinical isolate), three of Pseudomonas aeruginosa (ATCC27853 and two clinical isolates), and one clinical isolate each of Enterobacter cloacae, Enterobacter aerogenes, Klebsiella oxytoca, and Salmonella enteritidis (phage type 4). Tests were performed using the methodology described in the guidelines of the Comité de l'Antibiogramme de la Société Française de Microbiologie (CA-SFM, www.sfm.asso.fr). Briefly, a stock solution of each sample was prepared at $20 \mathrm{mg} / \mathrm{mL}$ in DMSO under sterile conditions. Serial dilutions were prepared (sample concentrations: 1, 10, 20, 30, 40, 50, 60, 80 and $100 \mu \mathrm{g} / \mathrm{mL}$ ) and $100 \mu \mathrm{L}$ of each dilution were added to $19.9 \mathrm{~mL}$ Mueller Hinton agar (Merck Germany) and transferred to Petri plates. Bacterial strains $\left(2 \times 10^{4}\right)$ were suspended in sterile $\mathrm{NaCl}$ aqueous solution $(0.15 \mathrm{M})$ and inoculated on the different Petri plates using the multipoint inoculator (AQS, England). After $24 \mathrm{~h}$ of incubation at $37^{\circ} \mathrm{C}$, the minimum inhibitory concentration ( $\mathrm{MIC}_{100} \mu \mathrm{g} / \mathrm{mL}$ ) of each sample against each bacterial strain was determined.

\section{RESULTS}

The propolis EtOH extract (E1a) did not show a significant polyphenol content $(18.2 \pm 2.9$ mg GAE/g); this unexpected finding was confirmed by the lack of phenolic components in the HPLC profile of E1a and by its lack of antioxidant activity when tested in the DPPH radical reduction assay. 
The sequential gradient extraction of the propolis sample using cyclohexane (E2), DCM (E3), EtOAc (E4), and $\mathrm{MeOH}(\mathbf{E 5})$ showed that the majority of the components were extracted into the most abundant (>60\%) low-polarity cyclohexane fraction (E2, Table 1), which exhibited a TLC profile very similar to that of E1a. None of the remaining fractions was obtained in more than $5 \%$ yield and none showed the presence of significantly important components by TLC. These results implied that the studied propolis was predominantly composed of non polar components in addition to beeswax. Since beeswax could be removed by cold filtration in $\mathrm{EtOH}, \mathbf{E 1 a}$ was chosen to carry out the chemical characterization of the propolis.

Flash chromatography purification of E1b yielded three major fractions (A, B and C; Fig. 1), which accounted for more than $70 \%$ of the total crude extract (Table 2). ${ }^{1} \mathrm{H}$ NMR analyses of E1a and fractions $\mathbf{A}, \mathbf{B}$ and $\mathbf{C}$ showed predominantly signals in the range of 0.8-3.0 ppm, with a few between 4.0-5.5 ppm, while the majority of the signals in the corresponding ${ }^{13} \mathrm{C}$ NMR spectra were located between 15 and $60 \mathrm{ppm}$, in addition to a few in the range of 110-150 ppm, that matches to triterpenes profiles. The GC/MS analysis of the most abundant fraction A, which showed a major low-polarity component by $\operatorname{TLC}\left(\mathrm{R}_{f}=0.70\right)$, allowed its identification as a mixture of $\alpha$ and $\beta$-amyrenone (I and II, respectively; structures of metabolites I-VIII are shown in Fig. 2), containing a small amount of $\alpha$-amyrin acetate (III). The TLC analysis of fraction $\mathbf{B}$ showed the presence of a single component $\left(\mathrm{R}_{f}=0.33\right)$ that proved to be inseparable under TLC conditions using a number of solvent systems; GC/MS analysis of $\mathbf{B}$ allowed the identification of the main component as a mixture of $\alpha$-amyrin (IV, major) and $\beta$-amyrin (V, minor). Finally, the GC/MS analysis of the least-abundant fraction C, which showed a major high-polarity component in its TLC profile $\left(\mathrm{R}_{f}=0.18\right)$, allowed its identification as a mixture of sterols, with fucosterol (VI) being the major component, and a mixture of $\beta / \gamma$-sitosterol (VII/VIII) being the minor one. 
Evaluation of the antimicrobial activities of E1b and fractions A, B and $\mathbf{C}$ showed that they did not exhibit neither antifungal nor antibacterial activities when tested towards two fungal species $\left(\mathrm{MIC}_{80}>250 \mu \mathrm{g} / \mathrm{mL}\right)$ and 21 bacterial strains $\left(\mathrm{MIC}_{100}>100 \mu \mathrm{g} / \mathrm{mL}\right)$, respectively. 


\section{DISCUSSION}

The results obtained in this investigation were unexpected since, to date, there are only a limited number of reports about triterpenoids occurring as major components in propolis (de Castro Ishida et al. 2011; Kalogeropoulos et al., 2009; Melliou et al., 2007; Furukawa et al. 2002; Ito et al. 2001; Velikova et al., 2000) and none of the propolis types that have been chemically described until now list triterpenes as their major components (Salatino et al. 2011; Sforcin and Bankova, 2011). Additionally, our results are not in agreement with reports stating that triterpenoids are rarely reported as propolis constituents because most chemical analyses of propolis samples are carried out with alcoholic extracts (Negri et al. 2003), or that triterpenoids are only occasionally collected by bees along with other classes of secondary metabolites such as phenolics (Negri et al. 2000).

The two plants used by the bees for their production of propolis in the region of Quintana Roo where the material was collected are commonly known with the Mayan names of "chakah" [Bursera simaruba (L.) Sarg.] and "tsalam" [Lysiloma latisiliquum (L.) Benth.] (Luis Ignacio Hernández-Chávez, personal communication), and both species are found as part of the flora of what is known as a mature medium-statured semideciduous forest (selva mediana) (Schultz, 2009). While no phytochemical knowledge exists about L. latisiliquum, the bark and resin of $B$. simaruba have been reported to contain lignans and other phenolic metabolites (Maldini et al., 2009; Peraza-Sánchez and Peña-Rodríguez, 1992), with the resin also reported to contain pentacyclic triterpenes such as the ubiquitous $\alpha$-amyrin (IV) and $\beta$-amyrin (V) (Peraza-Sánchez et al. 1995). Although no lignans could be detected in the analyzed samples, these findings could confirm the reported relationship that exists between the flora available to bees in a given region and the chemical composition of the propolis that they produce (Adelmann et al. 2007; Bankova, 2005a; de Castro Ishida et al. 2011; Daugsch et al. 2008; Salatino et al. 2011; Sforcin and Bankova, 2011) and the fact that in tropical regions, the 
chemical composition of the propolis can be highly variable because of the richness and versatility of the local flora (Trusheva et al. 2004).

Finally, it is well known that propolis is mainly used by bees as a defense material against parasites (Salatino et al. 2011) and to prevent bacterial and fungal infections and that often, while the biological activity of different propolis samples is similar, the secondary metabolites responsible for the activity can be different (Bankova, 2005b; Trusheva et al. 2006). Although E1a did not show significant antioxidant or antimicrobial activity, pentacyclic triterpenoids which include $\alpha$-amyrin (IV) and $\beta$-amyrin (V) and their various derivatives have been reported as antibacterials, antifungals and with cytotoxic activity (Choi et al. 2012; Chung et al. 2013; Cota et al. 2011; Irshad et al. 2013; Sharma et al. 2010); the lack of activity of both the propolis extract E1a and the purified fractions A-C in the assays for antioxidant and antimicrobial activity, suggests that the chemical composition of the propolis collected in Quintana Roo is of particular importance in the ecological interaction between the bees and the parasites and microorganisms that occur specifically in that region. Therefore additional research works will be needed to establish the mode of protective action of this Mexican propolis.

\section{ABBREVIATIONS USED}

ATCC American Type Culture Collection; CBS Central Bureau voor Schimmelcultures; $\mathbf{C D C l}_{3}$ Deuterated chloroform; DCM Dichloromethane; DMSO Dimethylsulfoxide; DPPH Diphenylpicrylhydrazyl; EtOAc Ethyl Acetate; GC/MS Gas Chromatography coupled with Mass Spectrometry; HPLC/DAD High Performance Liquid Chromatography coupled with

Diode Array Detector; MIC Minimum Inhibitory Concentration; NCCLS National Committee for Clinical Laboratory Standards; NMR Nuclear Magnetic Resonance; RPMI 
Roswell Park Memorial Institute; TLC Thin Layer Chromatography; UV Ultraviolet; YPDA Yeast Peptone Dextrose Agar.

\section{ACKNOWLEDGEMENTS}

We thank Dr Marie Kempf and Viviane Cassisa of the GEIHP (EA 3142/SFR 4208, University of Angers) for the microbiological assays. This work was supported by a research fellowship granted to LMPR by the "Region des Pays de Loire" (France).

\section{SUPPORTING INFORMATION}

HPLC profile of EtOH extract (E1a) and GC-MS data of E1b and fractions A-C are available in Supporting Information.

\section{REFERENCES}

ABDEL-LATEFF, A; KÖNIG, G M; FISCH, K M; HÖLLER, U; JONES, P G; WRIGHT, A D (2002) New antioxidant hydroquinone derivatives from the algicolous marine fungus Acremonium sp. Journal of Natural Product,s 65(11): 1605-1611. http://dx.doi.org/10.1021/np020128p

ADELMANN, J; PASSOS, M; BREYER, D H; DOS SANTOS, M H R; LENZ, C; LEITE N F; LANÇAS, F M; FONTANA, J D (2007) Exotic flora dependence of an unusual Brazilian propolis: the pinocembrin biomarker by capillary techniques. Journal of pharmaceutical and biomedical analysis, 43(1): 174-178. http://dx.doi.org/10.1016/j.jpba.2006.07.014

ALOMAR, K; GAUMET, V; ALLAIN, M; BOUET, G; LANDREAU A (2012) Synthesis, crystal structure, characterisation, and antifungal activity of 3-thiophene aldehyde semicarbazone (3STCH), 2,3-thiophene dicarboxaldehyde bis(semicarbazone) (2,3BSTCH2) and their nickel (II) complexes. Journal of Inorganic Biochemistry, 115: 36-43. http://dx.doi.org/10.1016/j.jinorgbio.2012.04.022 
BANKOVA, V (2005a) Chemical diversity of propolis and the problem of standardization. Journal of Ethnopharmacology, 100(1-2): 114-117. http://dx.doi.org/10.1016/j.jep.2005.05.004

BANKOVA, V (2005b) Recent trends and important developments in propolis research. EvidenceBased Complementary and Alternative Medicine, 2(1): 29-32. http://dx.doi.org/10.1093/ecam/neh059

BANKOVA, V; DE CASTRO, S L; MARCUCCI, M C (2000) Propolis: recent advances in chemistry and plant origin. Apidologie, 31: 3-15. http://dx.doi.org/10.1051/apido:2000102

CASTALDO, S; CAPASSO, F (2002) Propolis, an old remedy used in modern medicine. Fitoterapia, 73 (suppl 1): S1-S6. http://dx.doi.org/10.1016/S0367-326X(02)00185-5

CASTRO ISHIDA (DE), V F; NEGRI, G; SALATINO, A; BANDEIRA, M F C L (2011) A new type of Brazilian propolis: Prenylated benzophenones in propolis from Amazon and effects against $\begin{array}{lllll}\text { cariogenic } & \text { bacteria. } & \text { Food } & \text { Chemistry, }\end{array}$ http://dx.doi.org/10.1016/j.foodchem.2010.09.089

CHOI, J W; CHO, E J; LEE, D G; CHOI, K; KU, J; PARK, K-W; LEE, S (2012) Antibacterial Activity of Triterpenoids from Clerodendron trichotomum. Journal of Applied Biological Chemistry, 55(3): 169-172. http://dx.doi.org/10.3839/jabc.2012.026

CHUNG, P Y; CHUNG, L Y; NAVARATNAM, P (2013) Transcriptional profiles of the response of methicillin-resistant Staphylococcus aureus to pentacyclic triterpenoids. PLoS One 8(2): e56687. http://dx.doi.org/10.1371/journal.pone.0056687

COTA, B B; JOHANN, S; OLIVEIRA, D M; SIQUEIRA, E P; SOUZA-FAGUNDES, E M; CISALPINO, P S; ALVES T M A; ZANI, C L (2011) Biological potential of Stillingia oppositifolia. Revista Brasileira de Farmacognosia, 21(1): 70-77. http://dx.doi.org/10.1590/S0102$\underline{695 X 2011005000016}$

COTTICA, S M; SAWAYA, A C H F; EBERLIN, M N; FRANCO, S L; ZEOULA, L M; VISENTAINER, J V (2011) Antioxidant activity and composition of propolis obtained by different 
methods of extraction. Journal of Brazilian Chemical Society, 22(5): 929-935. http://dx.doi.org/10.1590/S0103-50532011000500016

DAUGSCH, A; MORAES, C S; FORT, P; PARK, Y K (2008) Brazilian Red Propolis-Chemical Composition and Botanical Origin. Evidence-Based Complementary and Alternative Medicine, 5(4): 435-441. http://dx.doi.org/10.1093/ecam/nem057

FURUKAWA, S; TAKAGI, N; IKEDA, T; ONO, M; NAFADY, A M; NOHARA, T; SUGIMOTO, H; DOI, S; YAMADA, H (2002) Two novel long-chain alkanoic acid esters of lupeol from alecrimpropolis. Chemical \& pharmaceutical bulletin, 50(3): 439-440. http://www.ncbi.nlm.nih.gov/pubmed/11911218

GÜlÇIN, İ; BURSAL, E; ŞEHITOĞLU, M H; BILSEL, M; GÖREN, A C (2010) Polyphenol contents and antioxidant activity of lyophilized aqueous extract of propolis from Erzurum, Turkey. Food and Chemical Toxicology, 48(8-9): 2227-2238. http://dx.doi.org/10.1016/j.fct.2010.05.053

IRSHAD, M; AHMAD, A; ZAFARYAB, M; AHMAD, F; MANZOOR, N; SINGH, M; RIZVI, M M A (2013) Composition of Cassia fistula oil and its antifungal activity by disrupting ergosterol $\begin{array}{lllll}\text { biosynthesis. } & \text { Natural } & \text { 26oduct } & \text { communications, }\end{array}$ http://www.ncbi.nlm.nih.gov/pubmed/23513744

ITO, J; CHANG, F-R; WANG, H-K; PARK Y K; IKEGAKI, M; KILGORE, N; LEE K-H (2001) Anti-AIDS Agents. 48.1 Anti-HIV Activity of Moronic Acid Derivatives and the New MelliferoneRelated Triterpenoid Isolated from Brazilian Propolis. Journal of Natural Products, 64(10): 12781281. http://dx.doi.org/10.1021/np010211x

KALOGEROPOUlOS， N; KONTELES， $\mathrm{S}$ J; TROULlidOU E; MOURTZINOS， I; KARATHANOS, V T (2009) Chemical composition, antioxidant activity and antimicrobial properties of propolis extracts from Greece and Cyprus. Food Chemistry, 116(2): 452-461. http://dx.doi.org/10.1016/j.foodchem.2009.02.060 
KUJUMGIEV, A; TSVETKOVA, I; SERKEDJIEVA, Y; BANKOVA, V; CHRISTOV, R; POPOV, S (1999) Antibacterial, antifungal and antiviral activity of propolis of different geographic origin. Journal of Ethnopharmacology, 64(3): 235-240. http://dx.doi.org/10.1016/S0378-8741(98)00131-7

KUMAZAWA, S; HAMASAKA, T; NAKAYAMA, T (2004) Antioxidant activity of propolis of various geographic origins. Food Chemistry, 84(3): 329-339. http://dx.doi.org/10.1016/S0308$\underline{8146(03) 00216-4}$

LI, F; AWALE, S; TEZUKA, Y; ESUMI, H; KADOTA, S (2010) Study on the constituents of Mexican propolis and their cytotoxic activity against PANC-1 human pancreatic cancer cells. Journal of Natural Products, 73(4): 623-627. http://dx.doi.org/10.1021/np900772m

LONDONO OROZCO, A; AVILA ACEVEDO, J G; CANALES MARTINEZ, M M; HERNANDEZ DELGADO, C T; SERRANO, P R; FLORES ORTIZ, C M; DIAZ, A D; PENIERES CARRILLO, J G; GARCIA TOVAR, C G; CRUZ SANCHEZ, T A (2010) Antibacterial Comparative Study Between Extracts of Mexican Propolis and of Three Plants Which Use Apis mellifera for its Production. Journal of Animal and Veterinary Advances, 9(8): 1250-1254. http://dx.doi.org/10.3923/javaa.2010.1250.1254

LOTTI, C; CAMPO FERNANDEZ, M; PICCINELLI, A L; CUESTA-RUBIO, O; MÁRQUEZ HERNÁNDEZ, I; RASTRELLI, L (2010) Chemical Constituents of Red Mexican Propolis. Journal of Agricultural and Food Chemistry, 58(4): 2209-2213. http://dx.doi.org/10.1021/jf100070w

MARCUCCI, M C (1995) Propolis: chemical composition, biological properties and therapeutic activity. Apidologie, 26(2): 83-99. http://dx.doi.org/10.1051/apido:19950202

MALDINI, M; MONTORO P; PIACENTE, S; PIZZA C (2009) Phenolic compounds from Bursera simaruba Sarg. bark: Phytochemical investigation and quantitative analysis by tandem mass spectrometry. Phytochemistry, 70: 641-649. http://dx.doi.org/10.1016/j.phytochem.2009.02.009 
MELIOU, E; STRATIS, E; CHINOU, I (2007) Volatile constituents of propolis from various regions of Greece - Antimicrobial activity. Food Chemistry, 103(2): 375-380. http://dx.doi.org/ $\underline{10.1016 / \text { j.foodchem.2006.07.033 }}$

Miguel, M G; NUNES, S; DANDLEN, S A; CAVACO, A M; ANTUNES, M D (2010) Phenols and antioxidant activity of hydro-alcoholic extracts of propolis from Algarve, South of Portugal. Food and Chemical Toxicology, 48(12): 3418-3423. http://dx.doi.org/10.1016/j.fct.2010.09.014

NATIONAL COMMITTEE FOR CLINICAL LABORATORY STANDARDS (1997), Reference Method for Broth Dilution Antifungal Susceptibility Testing of Yeasts, Approved standard M27-A, Villanova, PA. .

NATIONAL COMMITTEE FOR CLINICAL LABORATORY STANDARDS (2002), Reference Method for Broth Dilution Antifungal Susceptibility Testing of Filamentous Fungi, Approved standard, NCCLS Document M38-A., Clinical and Laboratory Standards Institute, Villanova, PA. .

NEGRI, G; MARCUCCI, MC; SALATINO, A; SALATINO, M L F (2000) Comb and propolis waxes from Brazil: Triterpenoids in propolis waxes - International Bee Research Association. Journal of Apicultural Research, 39(1-2): 86-88. http://www.ibra.org.uk/articles/20091216 12

NEGRI, G; SALATINO, M L F; SALATINO, A (2003) Unusual chemical composition of a sample of Brazilian propolis, as assessed by analysis of a chloroform extract - International Bee Research Association. Journal of Apicultural Research, 42(4): 53-56. http://www.ibra.org.uk/articles/20080613_23

OTA, C; UNTERKIRCHER, C; FANTINATO, V; SHIMIZU, M T (2001) Antifungal activity of propolis on different species of Candida. Mycoses, 44(9-10): 375-378. http://dx.doi.org/10.1046/j.1439-0507.2001.00671.x 
PARK, Y K; ALENCAR, S M; AGUIAR, C L (2002) Botanical origin and chemical composition of Brazilian propolis. Journal of agricultural and food chemistry, 50(9): 2502-2506. http://dx.doi.org/10.1021/jf011432b

PERAZA-SÁNCHEZ, S R; PEÑA-RODRÍGUEZ, L M (1992) Isolation of Picropolygamain from the Resin of Bursera simaruba. Journal of Natural Products, 55(12): 1768-1771. http://dx.doi.org/10.1021/np50090a009

PERAZA-SÁNCHEZ, S R; SALAZAR-AGUILAR, N E; PEÑA-RODRÍGUEZ, L M (1995) A New Triterpene from the Resin of Bursera simaruba. Journal of Natural Products, 58(2): 271-274. http://dx.doi.org/10.1021/np50116a019

PINO, J A; MARBOT, R; DELGADO, A; ZUMÁRRAGA, C; SAURI, E (2006) Volatile Constituents of Propolis from Honey Bees and Stingless Bees from Yucatán. Journal of Essential Oil Research, 18(1): 53-56. http://dx.doi.org/10.1080/10412905.2006.9699384

POPOVA, M; SILICI, S; KAFTANOGLU, O; BANKOVA, V (2005) Antibacterial activity of Turkish propolis and its qualitative and quantitative chemical composition. Phytomedicine, 12(3): 221-228. http://dx.doi.org/10.1016/j.phymed.2003.09.007

RAGHUKUMAR, R; VALI, L; WATSON, D; FEARNLEY, J; SEIDEL, V (2010) Antimethicillinresistant Staphylococcus aureus (MRSA) activity of 'pacific propolis' and isolated prenylflavanones. Phytotherapy Research, 24(8): 1181-1187. http://dx.doi.org/10.1002/ptr.3096

REBIAI, A; LANEZ, T; BELFAR, M L (2011) In vitro evaluation of antioxidant capacity of Algerian propolis by spectrophotometrical and electrochemical assays. International Journal of Pharmacology, 7(1): 113-118. http://dx.doi.org/10.3923/ijp.2011.113.118

SALATINO, A; FERNANDES-SILVA, C C; RIGHI, A A; SALATINO, M L F (2011) Propolis research and the chemistry of plant products. Natural Product Reports, 28(5): 925-936. http://dx.doi.org/10.1039/C0NP00072H 
SALATINO, A; TEIXEIRA, E W; NEGRI, G; MESSAGE, D (2005) Origin and Chemical Variation of Brazilian Propolis. Evidence-based Complementary and Alternative Medicine, 2(1): 33-38. http://dx.doi.org/10.1093/ecam/neh060

SAWAYA, A C H F; PALMA, A M; CAETANO, F M; MARCUCCI, M C; DA SILVA CUNHA, I B; ARAUJO, C E P; SHIMIZU, M T (2002) Comparative study of in vitro methods used to analyze the activity of propolis extracts with different compositions against species of Candida. Letters in Applied Microbiology, 35(3): 203-207. http://dx.doi.org/10.1046/j.1472-765X.2002.01169.x

SCHULTZ, G P (2009) Vascular flora of the El Edén Ecological Reserve, Quintana Roo, Mexico1. The Journal of the Torrey Botanical Society, 132(Apr 2005): 311-322. http://dx.doi.org/10.3159/1095-5674(2005)132[311:VFOTEE]2.0.CO;2

SFORCIN, J M; BANKOVA, V (2011) Propolis: Is there a potential for the development of new drugs? Journal of Ethnopharmacology, 133(2): 253-260. http://dx.doi.org/10.1016/j.jep.2010.10.032

SHARMA, S; SINGH, T; VIJAYVERGIA, R (2010) Antimicrobial properties of $\beta$-Amyrin (Terpenoid). JPR: BioMedRx: An International Journal, 3(8): 1979-1980. http://jpronline.info/index.php/jpr/article/view/3383

TOLOSA, L; CANIZARES, E (2002) The collection, characterisation and evaluation of antimicrobial of propolis extracts from Campeche, Mexico. Ars Pharmaceutica, 43(1-2): 187-204. http://farmacia.ugr.es/ars/articuloen.php?233

TRUSHEVA, B; POPOVA, M; BANKOVA, V; SIMOVA, S; MARCUCCI, M C; MIORIN, P L; DA ROCHA PASIN, F; TSVETKOVA, I (2006) Bioactive Constituents of Brazilian Red Propolis. Evidence-based Complementary and Alternative Medicine, 3(2): 249-254. http://dx.doi.org/10.1093/ecam/nel006 
TRUSHEVA, B; POPOVA, M; NAYDENSKI, H; TSVETKOVA, I; GREGORIO RODRIGUEZ, J; BANKOVA, V (2004) New polyisoprenylated benzophenones from Venezuelan propolis. Fitoterapia, 75(7-8): 683-689. http://dx.doi.org/10.1016/j.fitote.2004.08.001

VELAZQUEZ, C; NAVARRO, M; ACOSTA, A; ANGULO, A; DOMINGUEZ, Z; ROBLES, R; ROBLES-ZEPEDA, R; LUGO, E; GOYCOOLEA, F M; VELAZQUEZ, E F; ASTIAZARAN, H; HERNANDEZ, J (2007) Antibacterial and free-radical scavenging activities of Sonoran propolis. Journal of Applied Microbiology, 103(5): 1747-1756. http://dx.doi.org/10.1111/j.1365$\underline{2672.2007 .03409 . x}$

VELIKOVA, M; BANKOVA, V; MARCUCCI, M C, TSVETKOVA, I; KUJUMGIEV, A (2000) Chemical composition and biological activity of propolis from Brazilian meliponinae. Zeitschrift für Naturforschung, 55c: 785-789. 


\section{ILLUSTRATIONS AND GRAPHICS}

Figure 1. TLC profiles of E1b and fractions A, B and C.

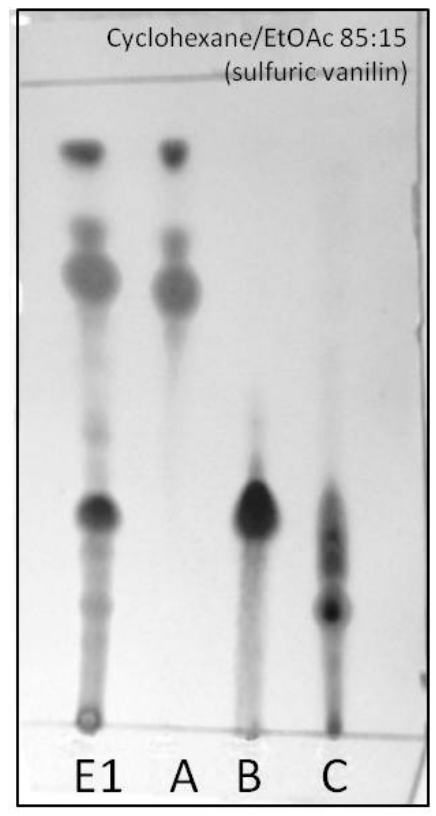

Figure 2. Structures of major constituents identified in E1b and fractions A, B and C by GC-

MS analyses
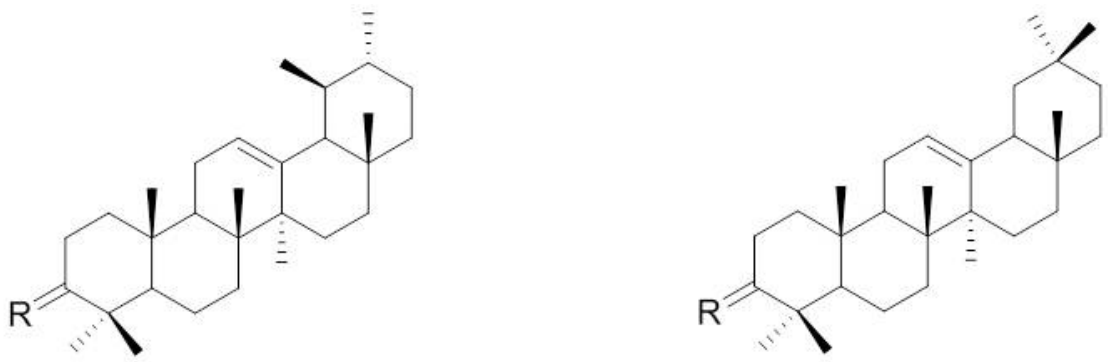

R: O, $\alpha$-amyrenone I (A)

R: $\alpha=\mathrm{H}, \beta=\mathrm{OAc}, \alpha$-amyrin acetate III (A)

R: $\alpha=\mathrm{H}, \beta=\mathrm{OH}, \alpha$-amyrin IV (B)

R: O, $\beta$-amyrenone II (A)

$\mathrm{R}: \alpha=\mathrm{H}, \beta=\mathrm{OH}, \beta$-amyrin V $(\mathrm{B})$

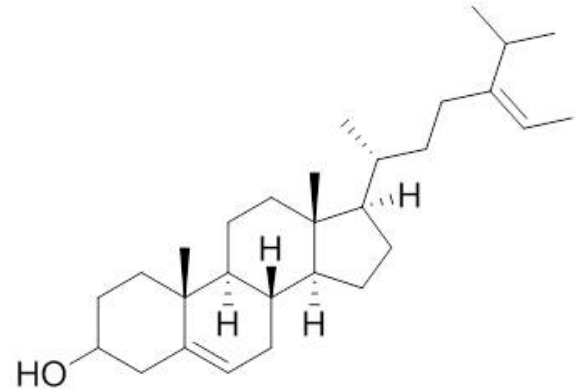

Fucosterol VI (C)

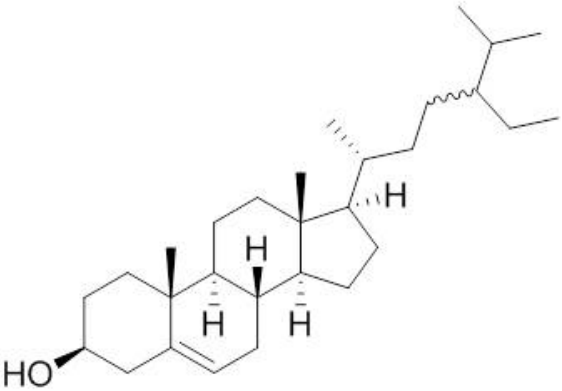

$\beta / \gamma$-sitosterol VII/VIII (C) 


\section{TABLES}

Table 1. Yields of propolis extracts

\begin{tabular}{lll}
\hline Extract & Solvent & $\begin{array}{l}\text { Extraction } \\
\text { yield (\%) }\end{array}$ \\
\hline E1a & EtOH & 34.2 \\
\hline E2 & Cyclohexane & 61.6 \\
E3 & DCM & 2.5 \\
E4 & EtOAc & 1 \\
E5 & MeOH & 4.6 \\
\hline
\end{tabular}

Table 2. Yields of fractions $\mathbf{A}, \mathbf{B}$ and $\mathbf{C}$ and $\mathrm{R}_{f}$ values of their major components on TLC

\begin{tabular}{lll}
\hline Fraction & Yield (\%) & $\mathrm{Rf}^{*}$ \\
\hline $\mathbf{A}$ & 47.7 & $0.89,0.77, \mathbf{0 . 7 0}$ \\
$\mathbf{B}$ & 19.9 & $\mathbf{0 . 3 3}$ \\
C & 4.1 & $\mathbf{0 . 1 8}$ \\
Total & 71.7 & \\
\multicolumn{2}{l}{ *Eluant system: cyclohexane:EtOAc 85:15 }
\end{tabular}




\title{
Unusual chemical composition of a Mexican propolis collected in Quintana Roo, Mexico
}

\author{
Séverine Boisard, ${ }^{\mathrm{a}}$ Thi Huong Tho Huynh, ${ }^{\mathrm{a}}$ Fabiola Escalante-Erosa, ${ }^{\mathrm{b}}$ Luis \\ Ignacio Hernández-Chavez, ${ }^{\mathrm{c}}$ Luis Manuel Peña-Rodríguez, ${ }^{\mathrm{b}}$ and Pascal \\ Richomme $^{\mathrm{a}}$
}

${ }^{a}$ EA 921 SONAS/SFR 4207 QUASAV, Université d'Angers, 16 Bd Daviers ,49045 Angers Cedex 01, France

${ }^{b}$ Unidad de Biotecnologia, Centro de Investigación Cientifica de Yucatán, Mérida, Yucatán, México ${ }^{c}$ Instituto Superior de Felipe Carrillo Puerto, Carrillo Puerto Quintana Roo, México

\section{SUPPORTING INFORMATION}

List of supporting information:

Fig. S1. HPLC chromatographic profile of extract E1a at 254 (a), 280 (b) and $350 \mathrm{~nm}$ (c). Fig. S2a. GC chromatographic profile of fraction $\mathbf{A}$ Fig. S2b. MS spectra of components in fraction $\mathbf{A}$ Fig. S3a. GC chromatographic profile of fraction $\mathbf{B}$ Fig. S3b. MS spectra of components in fraction $\mathbf{B}$ Fig. S4a. GC chromatographic profile of fraction $\mathbf{C}$ Fig. S4b. MS spectra of components in fraction $\mathbf{C}$ Fig. S5a. GC chromatographic profile of extract E1b Fig. S5b. MS spectra of components in extract E1b 

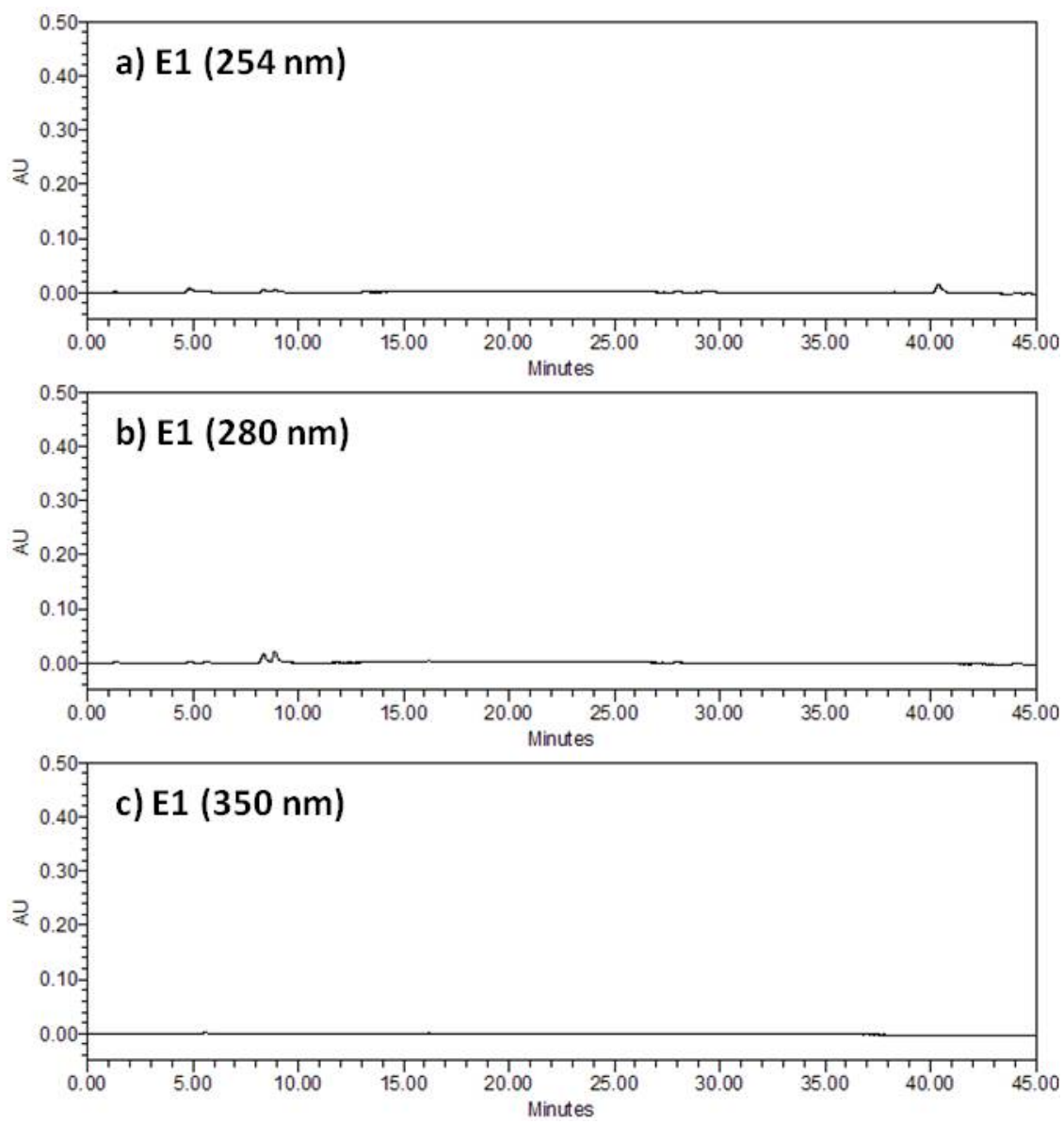

Fig. S1. HPLC chromatographic profile of EtOH extract (E1a) at 254 (a), 280 (b) and $350 \mathrm{~nm}$ (c). 


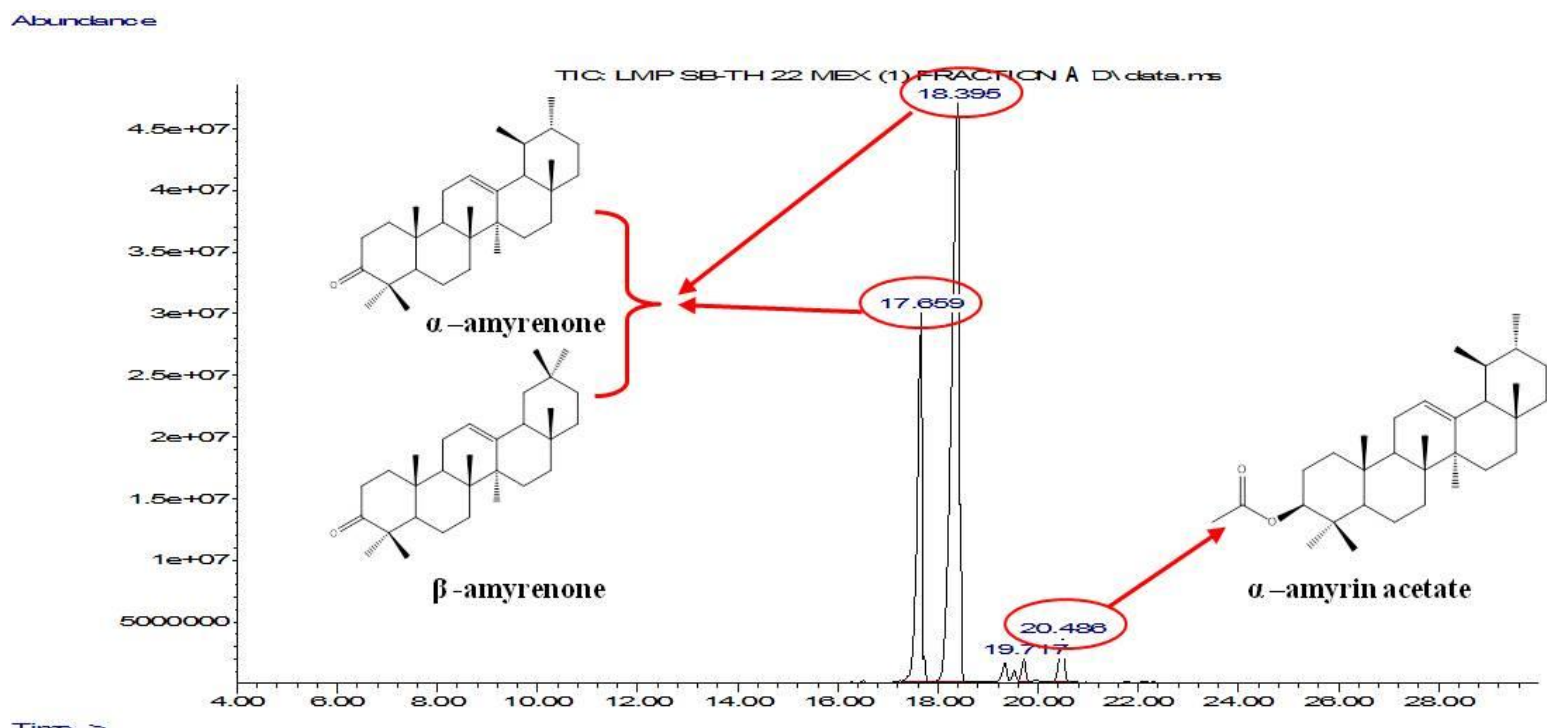

Fig. S2a. GC chromatographic profile of fraction $\mathbf{A}$

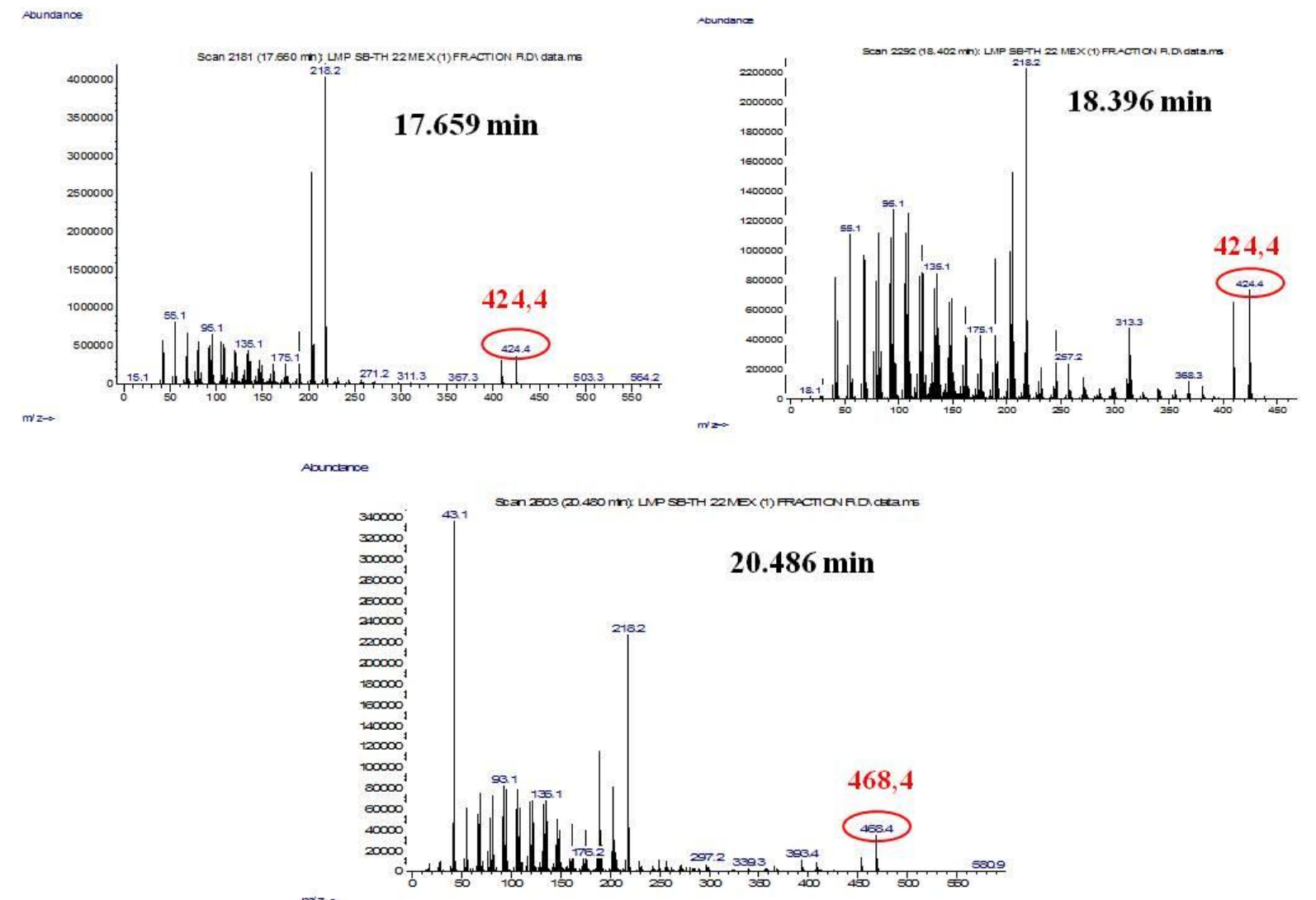

Fig. S2b. MS spectra of components in fraction $\mathbf{A}$ 


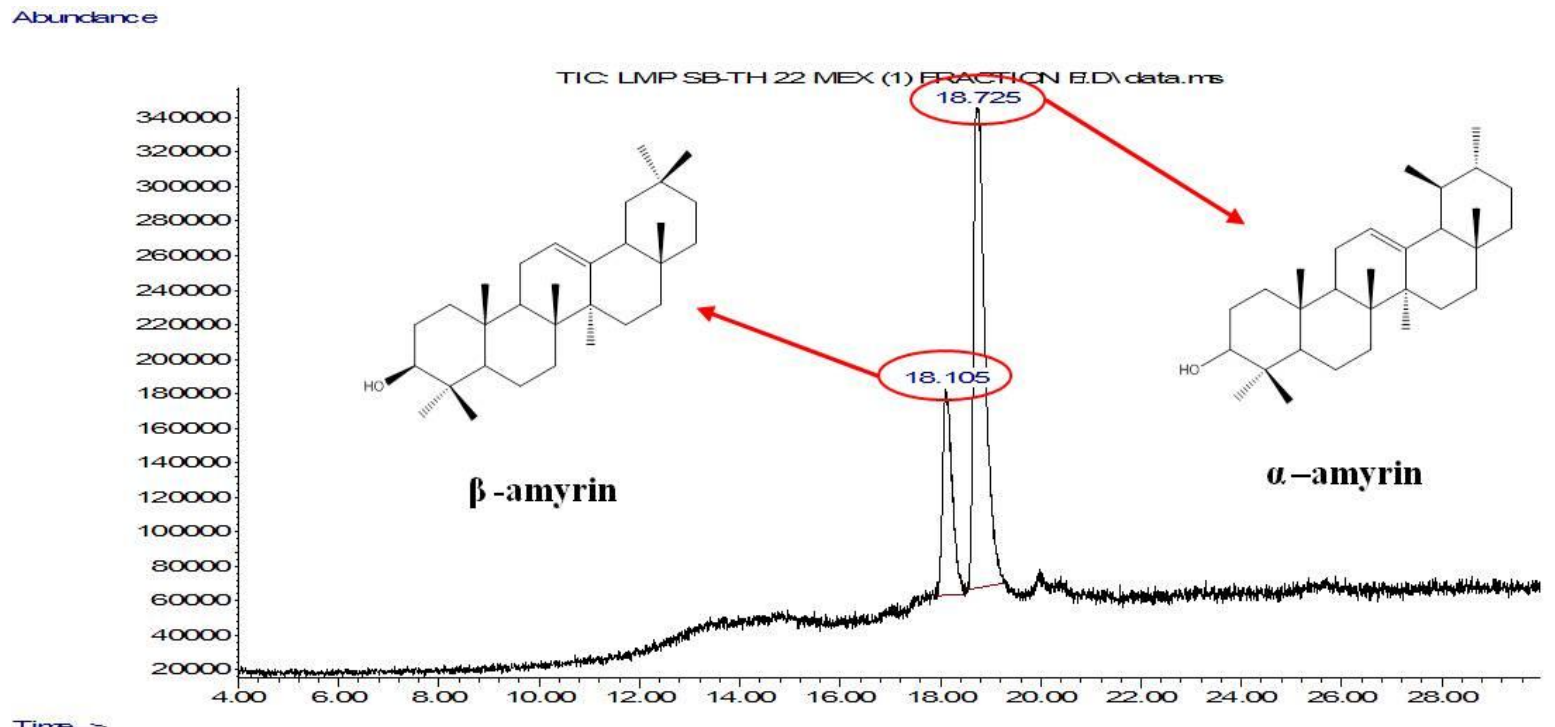

Fig. S3a. GC chromatographic profile of fraction $\mathbf{B}$

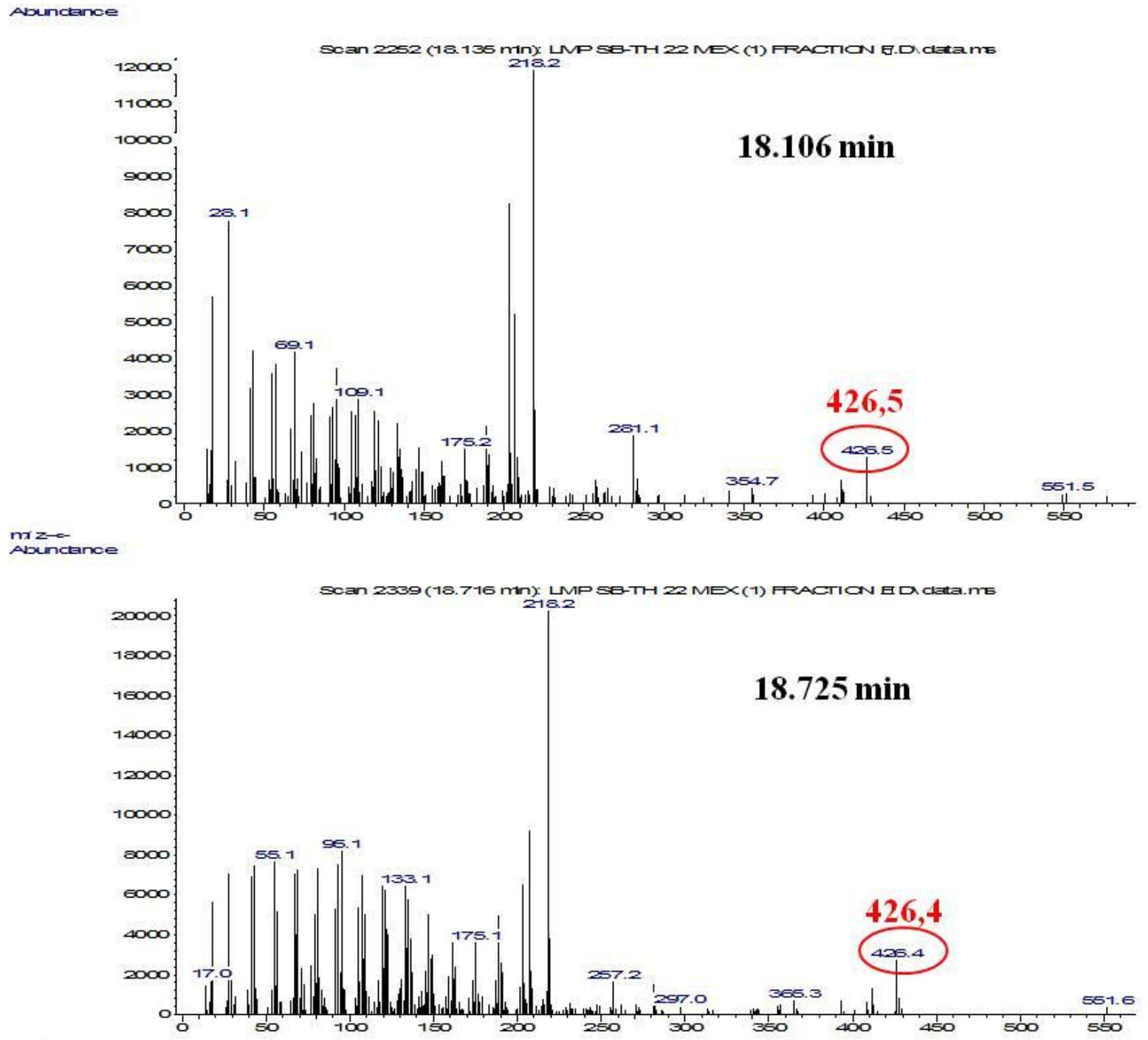

Fig. S3b. MS spectra of components in fraction $\mathbf{B}$ 


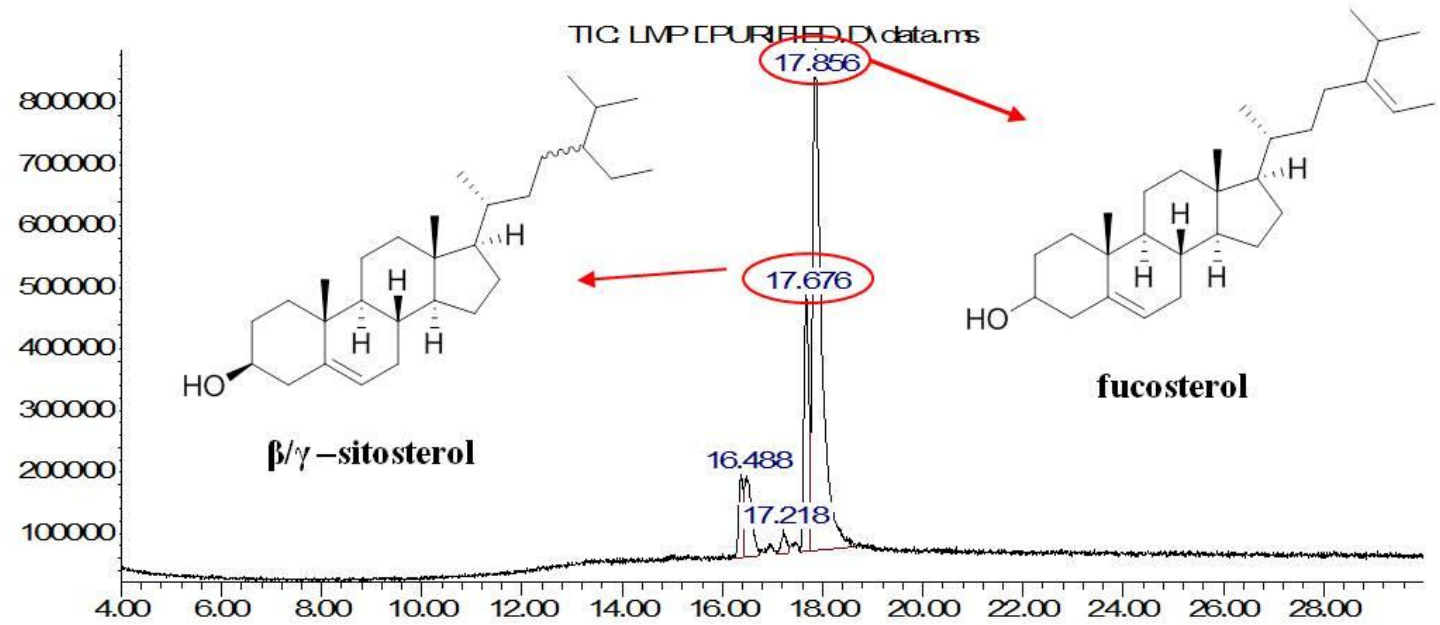

Fig. S4a. GC chromatographic profile of fraction $\mathbf{C}$

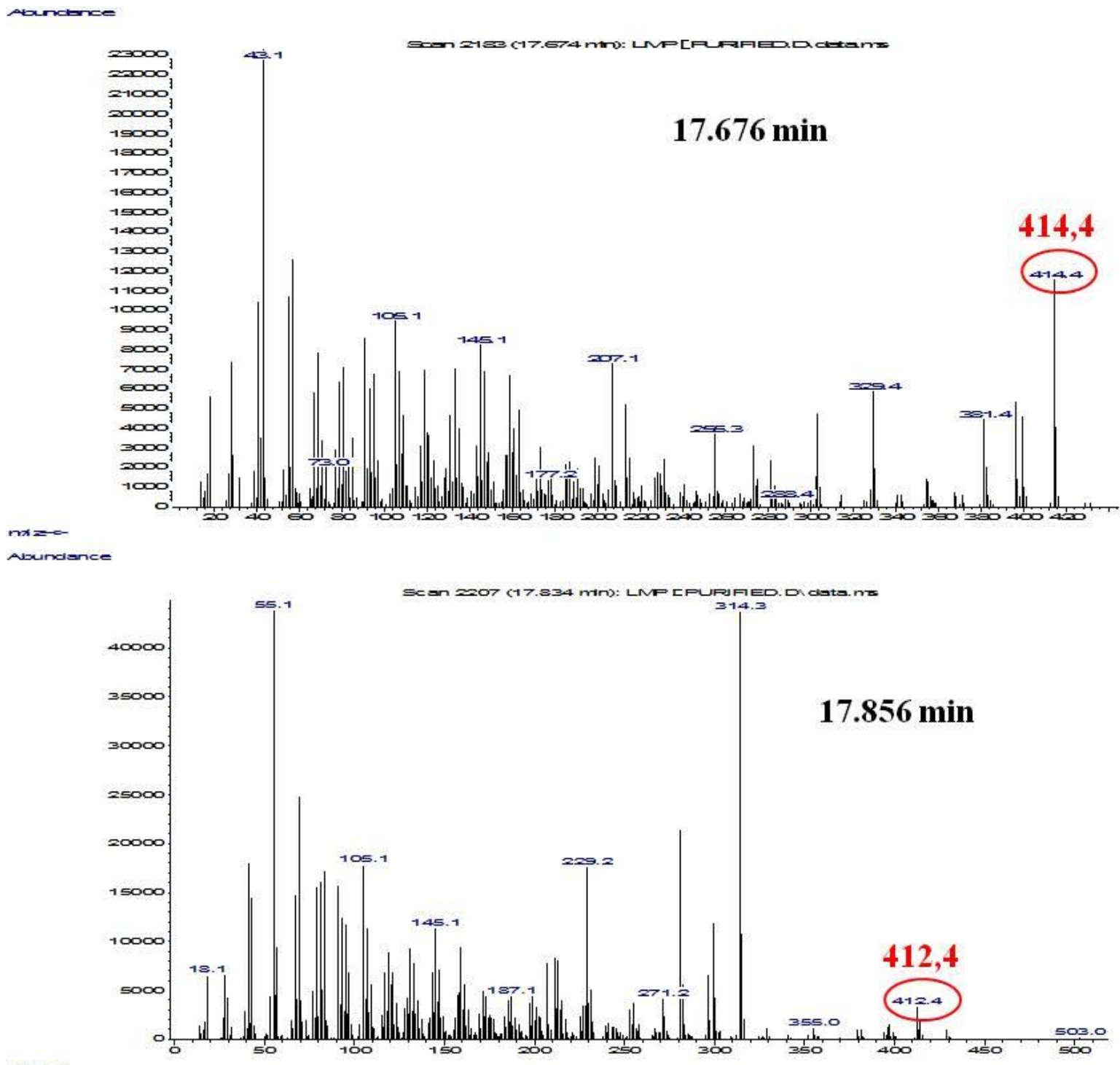

Fig. S4b. MS spectra of components in fraction $\mathbf{C}$ 


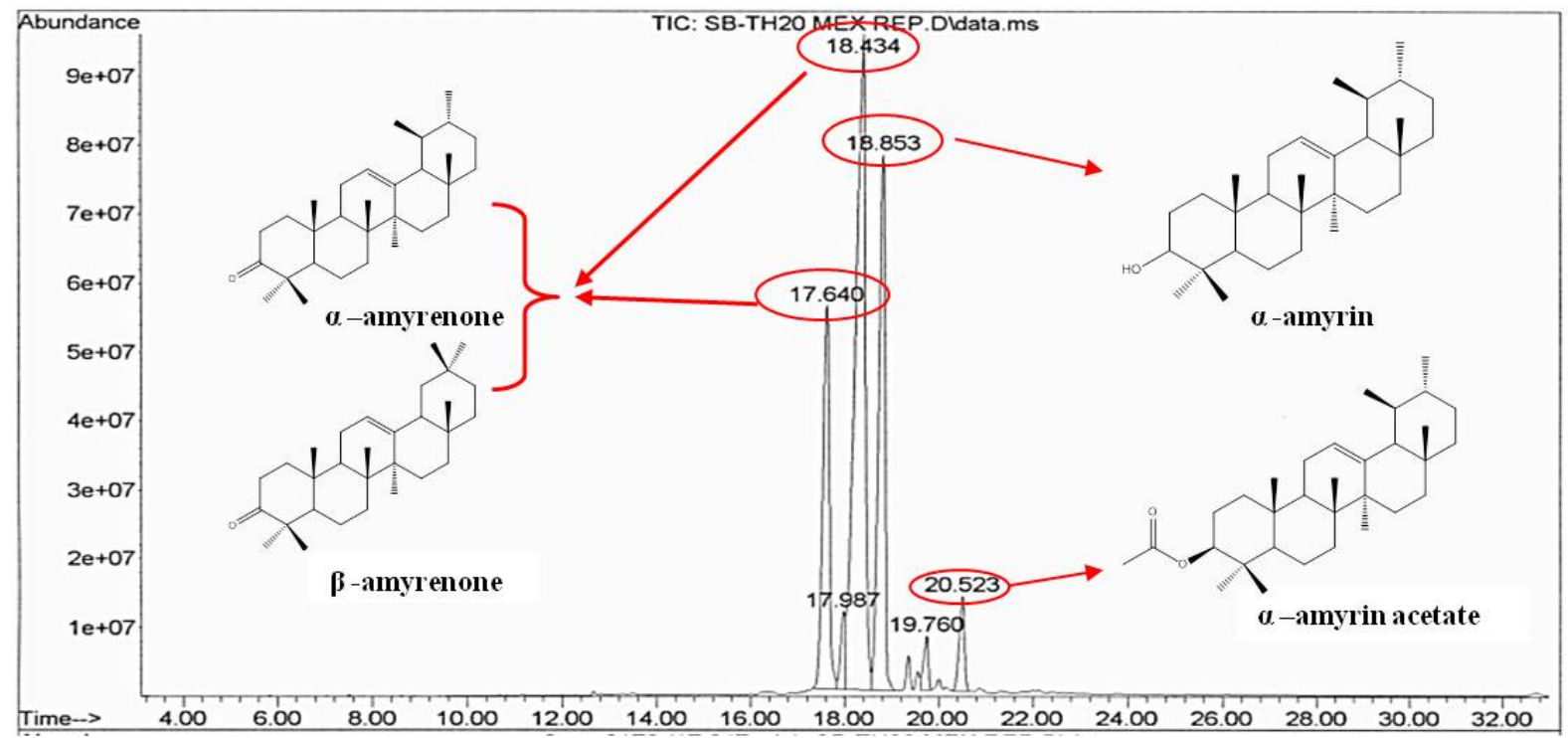

Fig. S5a. GC chromatographic profile of extract E1b
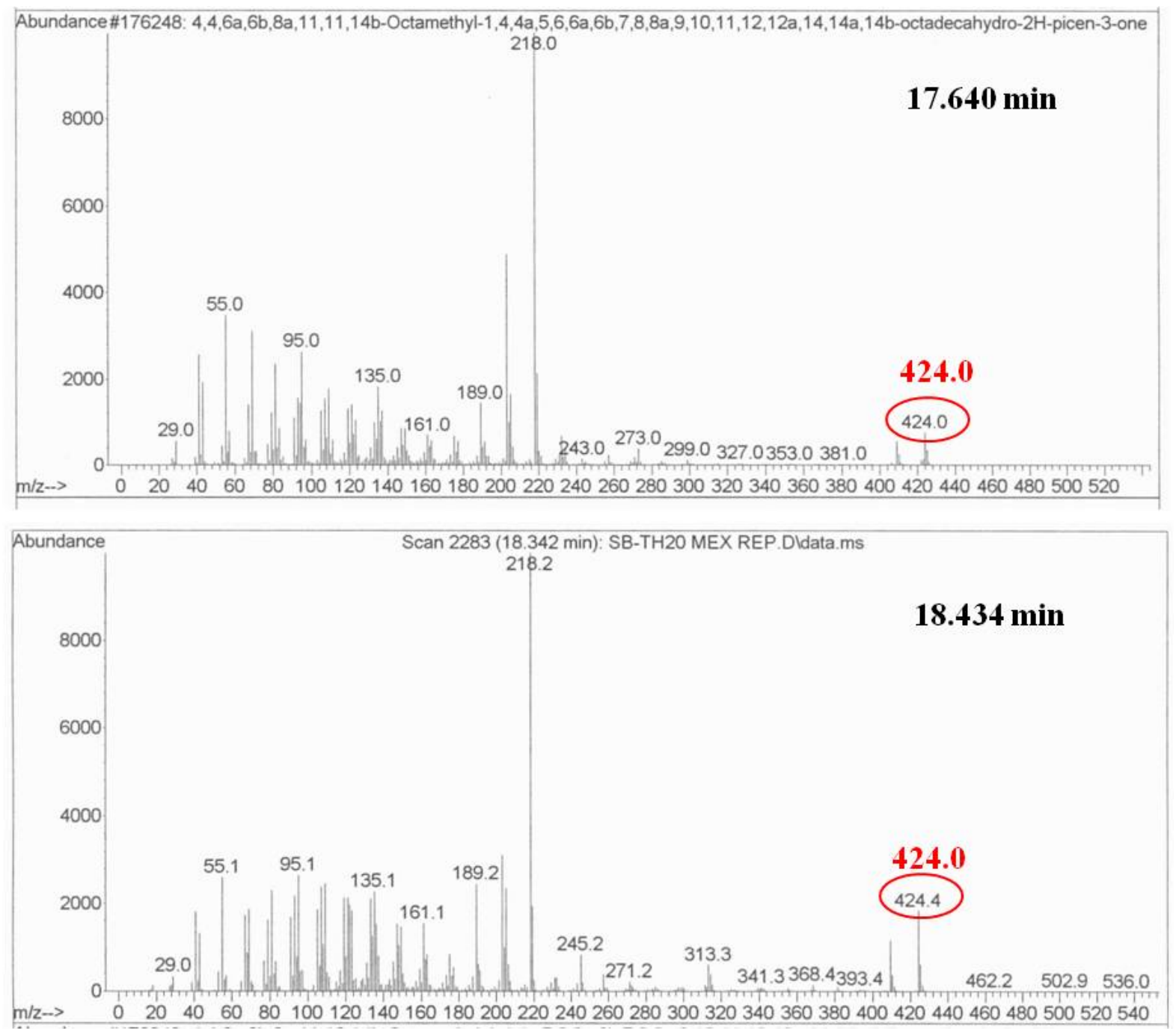

Fig. S5b-i). MS spectra of components in extract E1a (first part) 

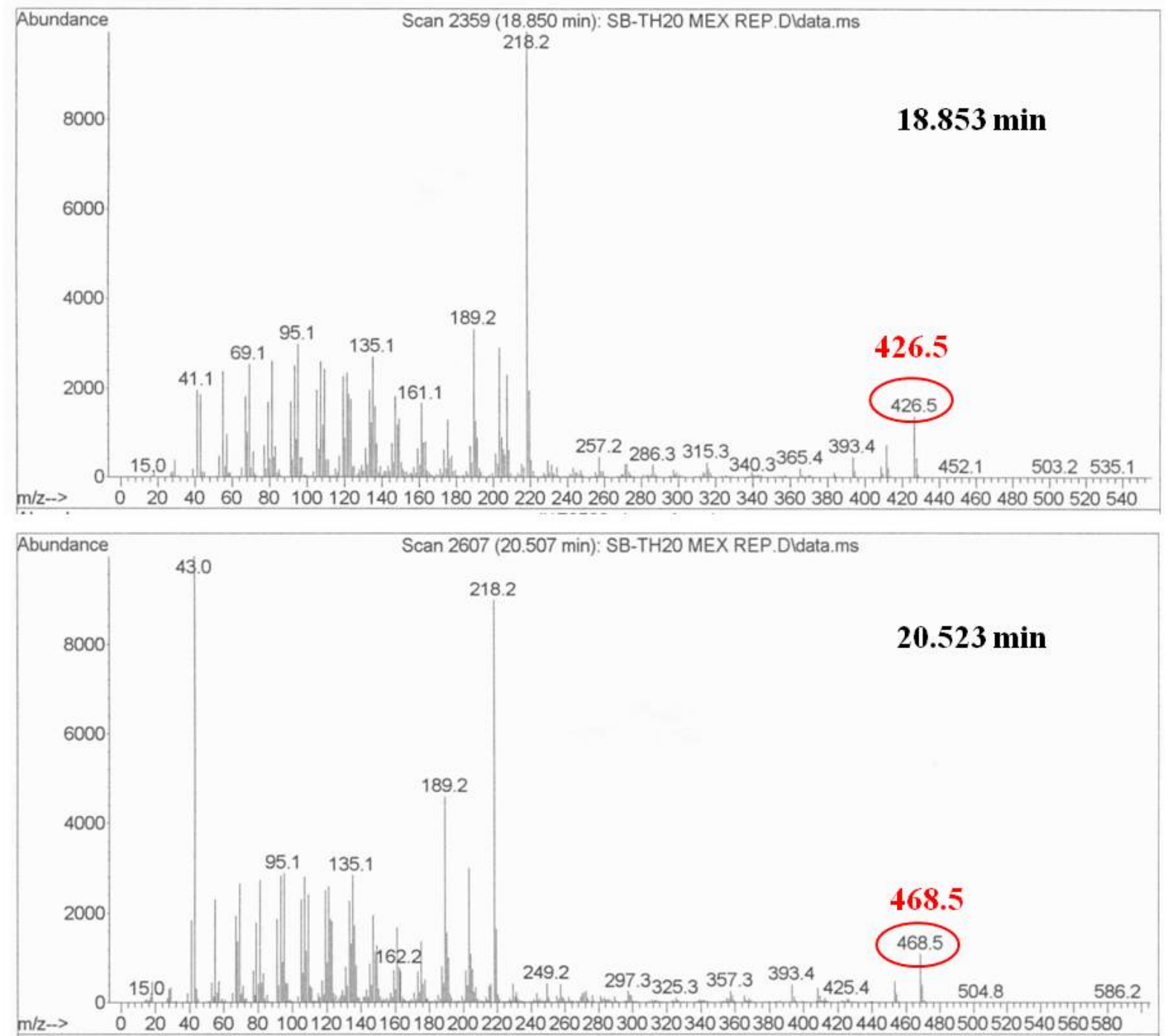

Fig. S5b-ii). MS spectra of components in extract E1a (second part) 